\title{
Pesantren Tradisional Sebagai Basis Pembelajaran Nahwu Dan Sharaf Dengan Menggunakan Kitab Kuning
}

\author{
Aliyah \\ Institut Agama Islam Negeri Palangka Raya \\ aliyah.albi@yahoo.com
}

\begin{abstract}
Traditional Islamic boarding school or pesantren is one of the oldest educational institutions in Indonesia, this is the center of the development of religious science, with books that use Arabic or called as the yellow book as the material being taught, to understand these books the students are taught first nahwu and sharaf or grammar as the science of tools to read, understand and interpret the contents of these books.

Seeing the important role of nahwu and sharaf in understanding religious sources, especially the Qur'an and hadits, the purpose of writing this article is: 1) the role of pesantren as a center for the development of religious knowledge, 2) the books of nahwu and sharaf taught in pesantren, 3) nahwu and sharaf learning methods.

This study uses the literature method, by examining several sources related to pesantren and learning nahwu and shraf by using the yellow books. This article concludes that the pesantren in the early days of the emergence of indeed the center of the development of religious science which originated in Arabic or yellow books, in pesantren the learning of nahwu and sharaf is the basis of the first knowledge taught because with this knowledge is the initial capital for the santri in understanding the other books, the books of nahwu and sharaf are taught, for the books of nahwu including, Awamil, Jurmiyah, Imriti, Mutammimah, Alfiyah, Qathran Nada', Qawaíd Al-I'rab, Qawaid Al-Lughah Al-Árabiyyah, and Nahwu Wadhih. Whereas the books of Sharaf,, Al-Bina'wa Al-Asas, Matan 'Izzi, Al-Maqshud fi Al-Sharf, Amtsilah Tashrifiyah, and Hall Al-Ma'qud Min Nazhm Al-Maqshud.
\end{abstract}

Keywords: Pesantren, Yellow Books, Nahwu, Sharaf, Learning, Method.

\section{Pendahuluan}

Pesantren adalah salah satu lembaga pendidikan tertua di Indonesia dan menjadi pusat pengembangan ilmu keislaman, Sebagai lembaga pendidikan tradisional umat Islam, pondok pesantren yang bertujuan mempelajari, memahami, mendalami, menghayati dan mengamalkan ajaran Islam dengan memberikan tekanan pada keseimbangan aspek perilaku (ahklak). Tidak menutup kemungkinan term pesantren akan membawa pada bayangan sebuah tempat menuntut ilmu agama yang ortodoks, statis, tertutup, dan tradisional. Pondok pesantren sebagai lembaga tertua di Indonesia memang senantiasa melestarikan 
nilai-nilai edukasi berbasis pengajaran tradisional. Pelestarian akan sistem dan metodologi tradisional itulah yang lantas menjadikan pesantren semodel ini disebut sebagai pesantren tradisional. Pelestarian nilai-nilai tersebut dapat dengan mudah dilacak dalam kehidupan santri yang sehari-harinya hidup dalam kesederhanaan, belajar tanpa pamrih dan penuh tanggung jawab, serta terikat oleh rasa solidaritas yang tinggi. ${ }^{1}$

Corak kehidupan tadi merupakan ekspresi kepribadian santri hasil dari tempaan pesantren tradisional yang juga sebagai pondasi awal santri untuk bergaul dengan masyarakat kelak. Kiai dalam tipologi macam ini merupakan figur sentral yang sikap sehari-harinya banyak mempengaruhi kepribadian santri. Karena itu, banyak orang yang beranggapan bahwa pendidikan di pondok pesantren tradisional seolah tidak mengenal libur, pembelajaran serta pengamalan ilmu berlaku siang dan malam dalam sepanjang tahun.

Dari kenyataan ini, masyarakat menganggap pesantren sebagai 'lembaga ideal' yang dipandang akan melahirkan alumni yang siap pakai serta mampu memenuhi kebutuhan spiritual masyarakat.

Ciri-ciri pesantren tradisional, yaitu pesantren yang dalam sistem pembelajarannya seorang murid menghadap guru sendiri-sendiri untuk dibacakan (diajarkan) oleh gurunya beberapa bagian dari kitab yang dipelajarinya, kemudian sang murid menirukannya berulang kali atau bisa disebut metode bandongan dan kiai atau ustadz membacakan kitab, menerjemah dan menerangkan. Sedangkan santri atau murid mendengarkan, menyimak dan mencatat apa yang disampaikan oleh kiai, ini bisa disebut dengan metode sorogan, begitu pula dalam materi yang diajarkan pun berasal dari kitab-kitab kuning, kitab berbahasa Arab karya ulama Islam baik luar maupun dalam negeri.

Di Indonesia, sejak permulaan abad ke-16 telah banyak dijumpai pesantren yang mengajarkan berbagai kitab Islam klasik dalam bidang fikih, teologi dan tasawuf. $^{2}$

Kitab-kitab Islam klasik biasanya dikenal dengan istilah 'kitab kuning' yang terpengaruh oleh warna kertas. Kitab-kitab tersebut ditulis oleh ulama-ulama

${ }^{1}$ Geertz, Abangan, Santri, dan Priyayi dalam Masyarakat Jawa, (Jakarta: Pustaka, 1981), hlm. 242 ${ }^{2}$ Amin Suma,dkk, Pondok Pesantren Al-Zaytun: Idealitas, Realitas dan Kontroversi, (Jakarta: Lembaga Penelitian Universitas Islam Negeri (UIN) Syarif Hidayatullah, 2002), hlm. 3 
zaman dulu yang berisikan tentang ilmu keislaman. Dalam hal ini terutama kitabkitab karangan ulama yang beraliran Syafi'iyah. Kitab-kitab klasik tersebut pada umumnya dapat dikelompokkan ke dalam delapan bidang, yaitu: (1) Nahwu dan șharf (tata bahasa Arab), (2) Fiqh, (3) Ușūl al-Fiqh, (4) Hadīì, (5) Tafsīr, (6) Tauhīd, (7) Tașawwuf dan etika, dan (8) cabang-cabang lain seperti tarikh (sejarah Islam) dan Balāghah (sastra Arab). Sistem pengajaran melalui kitab-kitab kuning telah menjadi karakteristik yang merupakan ciri khas dari proses belajar mengajar di pesantren. ${ }^{3}$

Kitab kuning merupakan sebuah elemen penting dalam sebuah pondok pesantren. Kitab kuning telah menjadi bahan ajar pesantren dalam kurun waktu yang lama sehingga kitab kuning memiliki posisi dan peran yang sangat signifikan di pesantren. Istilah kitab kuning memang sangat akrab dengan dunia pesantren. Pesantren dan kitab kuning adalah dua sisi yang tidak dapat terpisahkan dalam dunia pendidikan Islam di Indonesia. Martin Van Bruinessen menyebutkan bahwa mentransmisikan Islam tradisional sebagaimana yang terdapat dalam kitab kuning merupakan alasan pokok munculnya pesantren. ${ }^{4}$ Kitab kuning menjadi salah satu sistem nilai dalam kehidupan pesantren. Karena itu, pembelajaran dan pengkajian kitab kuning menjadi nomor satu dan merupakan ciri khas pondok pesantren.

Untuk memahami semua bidang keilmuan yang ada di pesantren yang semua kitabnya menggunakan bahasa arab maka diawal pembelajaran para santri diwajibkan mempelajari unsur bahasa yaitu tata bahasa atau nuhwu dan sharf, karena ilmu ini adalah pokok atau fondasi pertama untuk memahami kandungan yang ada di dalam kitab-kitab lainnya.

Untuk dapat membaca teks-teks bahasa Arab dengan baik, si pembaca harus menentukan syakl (fathah, kasroh, dhomah atau sukun). Hal ini membutuhkan kemampuan untuk mengetahui kedudukan kata dalam kalimat tersebut (Ilmu Nahwu) dan kemampuan untuk dapat menentukan bentuk kata tersebut (Ilmu Sharf). Untuk dapat menentukan bentuk kata tersebut juga harus dibantu dengan pemahaman terhadap teks yang dibaca (fahm almaqru') dan ia tidak dapat

${ }^{3}$ Faisal Ismail, Paradigma Kebudayaan Islam: Studi Kritis dan Refleksi Historis, Cet. ke-2 (Yogyakarta: Titian Ilahi Press, 1997), hlm. 116 -117.

${ }^{4}$ Martin Van Bruinessen, Kitab Kuning, Pesantren dan Tarekat, (Bandung: Mizan,1995), hlm. 17 
diperoleh tanpa penguasaan mufrodat. Dengan demikian untuk dapat membaca dan memahami literature bahasa Arab setidaknya harus menguasai ilmu-ilmu yang mendukung yaitu Ilmu Nahwu dan Sharaf, dan juga menguasai mufrodat sehingga ada sedikit gambaran tentang isi teks yang sedang dibacanya. Hal ini agaknya selaras dengan ungkapan orang Barat yang mengatakan bahwa” orang Eropa, dengan membaca dapat memahami teks tetapi orang Arab harus faham dulu baru dapat membaca teks dengan benar". 5

\section{Pesantren}

Pondok pesantren muncul pertama kali di Indonesia pada abad ke-16 M, yakni terdapat di Ampel Denta dalam asuhan Sunan Ampel. Pada waktu itu, beliau mengkader santri-santrinya untuk menyebarkan ajaran Islam ke seluruh pelosok tanah air, bahkan ada yang ditugaskan hingga ke negara-negara tetangga.

Dari murid-murid Sunan Ampel inilah, kemudian menjamur pesantrenpesantren di seluruh penjuru tanah air. Puncaknya adalah pada awal pertengahan abad ke-19 serta awal abad ke-20, yaitu pada masa Syekh Kholil Bangkalan. Dari tangan dingin beliaulah muncul kiai-kiai besar Nusantara yang kemudian dapat menetaskan kiai-kiai besar lainnya. Puncaknya, pada waktu itu hampir di setiap kota kecamatan hingga di setiap desa berdiri satu pesantren atau bahkan lebih. ${ }^{6}$

Salah satu tradisi agung (great tradition) di Indonesia adalah tradisi pengajaran agama Islam seperti yang muncul di pesantren Jawa dan lambagalembaga serupa di luar Jawa serta Semenanjung Malaya. Alasan pokok munculnya pesantren ini adalah untuk mentransmisikan Islam tradisional sebagaimana yang terdapat dalam kitab-kitab klasik yang ditulis berabad-abad yang lalu. Kitab-kitab ini dikenal di Indonesia sebagai kitab kuning.

Kata pesantren sendiri berasal dari kata 'santri', dengan awal pe di depan dan akhiran an yang berarti tempat tinggal para santri. Term santri menurut C.C. Berg berasal dari istilah 'shastri' yang dalam bahasa India berarti orang yang tahu buku-buku suci agama atau seorang yang ahli kitab suci. Sedangkan menurut Nurcholis Majid, istilah santri dapat dibedakan menjadi dua. Pertama, kata santri

${ }^{5}$ Taufiq Burj, Musykilat Ta'lim al-Arabiyyah Li Ghairi an-Nathiqina biha, dalam as-Sijl al-Ilm LiNadwah al Alamiyah Li Ta'lim al-Arabiyyah Li Ghairi an-Nathiqina biha,. (Riyad : Imadat Syu'un al-Maktabat, Kairo: Dar al-Ma'arif, 1980), hlm. 129

${ }^{6}$ Sutrisno, Sejarah Walisongo Misi Pengislaman di Tanah Jawa, (Yogyakarta: GRAHA Pustaka), hlm. 16 
berasal dari kata 'sastri' bahasa Sankskerta yang artinya melek huruf. Asumsi ini didasarkan bahwa kaum santri yang berusaha mendalami agama melalui kitabkitab bertuliskan dan berbahasa Arab menyebabkan para santri harus berusaha belajar bahasa Arab dan kedua, kata santri berasal dari bahasa Jawa dari kata 'cantrik' yang berarti seseorang yang selalu mengikuti seorang guru kemana guru ini pergi menetap. ${ }^{7}$

Berkenaan dengan hal tersebut, Zamakhsyari Dhofier, mengatakan, ada lima unsur pondok pesantren yang melekat atas dirinya yang meliputi: masjid, pondok, pengajaran kitab-kitab Islam klasik, santri dan Kyai. ${ }^{8}$

Kitab-kitab berbahasa arab yang diajarkan di pesantren biasa disebut dengan kitab kuning, para santri tidak bisa memahami kitab-kitab tersebut tampa memahami ilmu alat terlebih dahulu, ilmu alat itu adalah nahwu dan shraf atau tata bahasa, jadi para santri belajar ilmu nahwu dan sharaf agar bisa memahami kandungan yang ada didalam kitab-kitab berbahasa arab lainnya.

Kitab-kitab tersebut biasanya dikategorikan ke dalam tiga tingkatan, yaitu: (1) Kitab-kitab dasar, (2) Kitab-kitab menengah dan (3) kitab-kitab besar.

\section{Kitab Kuning}

Kitab klasik yang lebih dikenal dengan nama kitab kuning mempunyai peranan yang sangat penting dalam mengembangkan ajaran agama Islam Ini menunjukkan bahwa kitab kuning penting untuk dipelajari. Ilmuan Islam menulis karyanya berupa sebuah kitab yang berwarna unik yaitu kekuning-kuningan yang dipelajari di Pondok Pesantren.

Kitab Kuning sering disebut dengan istilah kitab klasik (Al kutub Alqadimah), kitab-kitab tersebut merujuk pada karya-karya tradisional ulama klasik dengan gaya bahasa Arab yang berbeda dengan buku modern. ${ }^{9}$ Ada juga yang mengartikan bahwa dinamakan kitab kuning karena ditulis diatas kertas yang berwarna kuning. Jadi, kalau sebuah kitab ditulis dengan kertas putih, maka akan disebut kitab putih, bukan kitab kuning. ${ }^{10}$

\footnotetext{
${ }^{7}$ Nurcholish Madjid, Kaki Langit Peradaban Islam (Jakarta: Paramadina,1997), hlm. 16.

${ }^{8}$ Zamakhsyari Dhofier, Tradisi Pesantren Studi Tentang Pandangan Hidup (Jakarta : LP3ES, 1985), hlm. 44-45

${ }^{9}$ Endang Turmudi. Perseligkuhan Kyai dan Kekuasaan. (Yogyakarta:Lkis. 2004), hlm..36

${ }^{10}$ Ahmad Barizi.Pendidikan Intregratif:Akar Tradisi \& Intregasi Keilmuan Pendidikan Islam. (Malang:UIN Maliki Press, 20011), hlm. 62
} 
Kitab yang berisi ilmu-ilmu keislaman, yang ditulis atau dicetak dengan huruf Arab dalam bahasa Arab. Kitab itu disebut "kitab kuning" karena umumnya dicetak di atas kertas berwarna kuning yang berkualitas rendah. Kadang-kadang lembar-lembaranya lepas tak terjilid sehingga bagian-bagian yang perlu mudah diambil. Biasanya, ketika belajar para santri hanya membawa lembaran-lembaran yang akan dipelajari dan tidak membawa kitab secara utuh. Ini sudah merupakan ciri khas dari kitab kuning itu sendiri sehingga kitab ini menjadi kitab yang unik untuk dipelajari karena dapat membawa lembaran-lembaran yang akan dipelajari tanpa harus membawa keseluruhan dari isi kitab tersebut. Menurut Azyumardi Azra, Kitab kuning adalah kitab-kitab keagamaan berbahasa Arab, Melayu, Jawa atau bahasa-bahasa lokal lain di Indonesia dengan menggunakan aksara Arab, yang selain ditulis oleh ulama di Timur Tengah, juga ditulis oleh ulama Indonesia sendiri, demikian menurut Azra, ini merupakan perluasan dari terminologi kitab kuning yang berkembang selama ini, yaitu kitab-kitab keagamaan berbahasa Arab, menggunakan aksara Arab, yang dihasilkan oleh para ulama dan pemikir Muslim lainnya di masa lampau khususnya yang berasal dari Timur Tengah. ${ }^{11}$

Melihat dari warna kitab ini yang unik maka kitab ini lebih dikenal dengan kitab kuning. Akan tetapi akhir-akhir ini ciri-ciri tersebut telah mengalami perubahan. Kitab kuning cetakan baru sudah banyak memakai kertas putih yang umum dipakai di dunia percetakan. Juga sudah banyak yang tidak "gundul" lagi karena telah diberi syakl untuk memudahkan santri membacanya. Sebagian besar kitab kuning sudah dijilid. Dengan demikian, penampilan fisiknya tidak mudah lagi dibedakan dari kitab-kitab baru yang biasanya disebut “al-kutub al-asriyyah" (buku-buku modern). Perbedaannya terletak pada isi, sistematika, metodologi, bahasa, dan pengarangnya. Meskipun begitu, julukan "kitab kuning" tetap melekat padanya.

Kitab kuning dipelajari terutama di pesantren memiliki bermacam-macam ilmu keagamaan untuk mengembangkan ajaran agama dan mengembangkan pendidikan agama bagi para santri, agar mereka mempunyai keyakinan yang kuat dalam melaksanakan ibadah.

\footnotetext{
${ }^{11}$ Azyumardi Azra, Pendidikan Islam:Tradisi dan Modernisasi Menuju Milenium Baru. (Jakarta:PT Logos Wacana Imu.1999), hlm. 111
} 
Di daerah asalnya, yaitu Timur Tengah, kitab kuning disebut "al-kutub alqadimah" (buku-buku klasik) sebagai sandingan dari “al-kutub al-asriyah" (buku-buku modern). Al-kutub al-asriyah yang beredar di Indonesia (di kalangan pesantren) sangat terbatas jenisnya. Dari kelompok ilmu-ilmu syariat, yang sangat dikenal ialah kitab-kitab ilmu fiqih, tasawuf, tafsir, hadist, tauhid (aqidah), dan tarekh (terutama sirah nabawiyyah, sejarah hidup Nabi Muhammmad SAW). Dari kelompok ilmu-ilmu nonsyariat, yang banyak dikenal ialah kitab-kitab nahwu saraf, yang mutlak diperlukan sebagai alat bantu untuk memperoleh kemampuan membaca kitab gundul. Dapat dikatakan bahwa kitab kuning yang banyak beredar di kalangan pesantren adalah kitab yang berisi ilmu-ilmu syariat, khususnya ilmu fikih. Kitab syariat seperti fikih, tasauf, tafsir, hadits, tauhid, tarih, dan kitab nonsyariat seperti nahwu dan saraf, semuanya ditulis dalam bahasa Arab pada kertas yang kuning dan tidak memakai baris (kitab gundul) sehingga kitab ini juga disebut dengan kitab kuning.

Ada tiga ciri umum kitab kuning. Pertama, penyajian setiap materi dalam satu pokok bahasan selalu diawali dengan mengemukakan definisi-definisi yang tajam, yang memberi batasan pengertian secara jelas untuk menghindari salah pengertian terhadap masalah yang sedang dibahas. Kedua, setiap unsur materi bahasan diuraikan dengan segala syarat-syarat yang berkaitan dengan objek bahasan bersangkutan. Ketiga, pada tingkat syarah (ulasan atau komentar) dijelaskan pula argumentasi penulisnya, lengkap dengan penunjukan sumber hukumnya. $^{12}$

Kitab kuning dilihat dari sudut pandang memiliki berberapa unsur yang penting untuk diketahui maka dari sudut pandang inilah dapat kita ketahui dan dapat kita pahami arti dari kitab kuning. Di antara sudut pandang itu adalah:

1. Kandungan maknanya.

2. Kadar penyajian.

3. Kreativitas penulisan.

4. Penampilan uraian.

Dilihat dari kandungan maknanya, kitab kuning dapat dikelompokkan menjadi dua macam, yaitu: 1) Kitab kuning yang berbentuk penawaran atau penyajian ilmu secara polos (naratif ) seperti sejarah, hadis, dan tafsir; dan 2)

${ }^{12}$ Abdul Aziz Dahlan, dkk, Suplemen Ensiklopedia Islam, (Jakarta: PT. Iktiar Baru), hlm. 334 
kitab kuning yang menyajikan materi yang berbentuk kaidah-kaidah keilmuan seperti nahwu, usul fikih, dan mustalah al-hadis (istilah-istilah yang berkenaan dengan hadis).

Sementara itu, dilihat dari kadar penyajiannya, kitab kuning dapat dibagi atas tiga macam, yaitu: 1) mukhtasar, yaitu kitab yang tersusun secara ringkas dan menyajikan pokok-pokok masalah, baik yang muncul dalam bentuk nazam atau syi'r (puisi) maupun dalam bentuk nasr (prosa), 2) syarah, yaitu kitab kuning yang memberikan uraian panjang lebar, menyajikan argumentasi ilmiah secara komparatif, dan banyak mengutip ulasan ulama dengan argumentasi masingmasing; dan 3) kitab kuning yang penyajian materinya tidak terlalu ringkas tetapi juga tidak terlalu panjang(mutawassitah).

Dilihat dari kreativitas penulisannya, kitab kuning dikelompokkan menjadi tujuh macam. 1) kitab kuning yang menampilkan gagasan-gagasan baru, seperti Kitab ar-Risalah (kitab usul fikih) karya Imam Syafi'i, al-Arud wa al-Qawafi (kaidah-kaidah penyusunan syair) karya Imam Khalil bin Ahmad al-Farahidi, atau teori-teori ilmu kalam yang dimunculkan Wasil bin Ata, Abu Hasan al Asy’ari dan lain-lain. 2) Kitab kuning yang muncul sebagai penyempurnaan terhadap karya yang telah ada, sebagai Kitab Nahwu (tata bahasa Arab) karya as-Sibawaih yang menyempurnakan karya Abul Aswad ad-Duwali. 3) Kitab kuning yang berisi komentar (syarah) terhadap kitab yang telah ada, seperti Kitab Hadis karya Ibnu Hajar al-Asqalani yang memberikan komentar terhadap kitab Sahih alBukhari. 4 ) Kitab kuning yang meringkas karya yang panjang lebar, seperti Alfiah Ibn Malik (buku tentang nahwu yang disusun dalam bentuk syair sebanyak 1.000 bait) karya Ibnu Aqil dan Lubb al-Usul (buku tentang usul fikih) karya Zakaria al-Alansari sebagian ringkasan dari Jam' al-Jawani' karangan as-Subki. 5) Kitab kuning yang berupa kutipan dari berbagi kitab lain, seperti Ulum AlQur'an (buku tentang ilmu-ilmu Al-Qur'an) karya al-Aufi. 6) Kitab kuning yang memperbaharui sistematika kitab-kitab yang telah ada, seperti Kitab Ihya Ulum ad-Din karya Imam al-Gazali. 7) Kitab kuning yang berisi kritik dan koreksi terhadap kitab-kitab yang telah ada, seperti Kitab Mi'yar al-Ilm (sebuah buku yang meluruskan kaidah-kaidah logika) karya al-Gazali.

Adapun dilihat dari penampilan uraiannya, kitab kuning memiliki lima dasar yaitu: 1) Mengulas pembagian sesuatu yang umum menjadi khusus, sesuatu yang 
ringkas menjadi terperinci, dan seterusnya. 2) Menyajikan redaksi yang teratur dengan menampilkan beberapa pernyataan dan kemudian menyusun kesimpulan. 3) Membuat ulasan tertentu ketika mengulangi uraian yang dianggap perlu, sehingga penampilan materinya menarik dan pola pikirnya dapat lurus. 4) Memberikan batasan-batasan jelas ketika penulisnya menurunkan sebuah definisi. dan 5) Menampilkan beberapa ulasan dan argumentasi terhadap pernyataan yang dianggap perlu. ${ }^{13}$

Maka dapatlah dikelompokan kitab kuning berdasarkan kepada cirinya, kandungan maknanya, kadar penyajiannya, kreativitas penulisannya, penampilan uraiannya, dari keseluruhan kitab kuning yang dipelajari ataupun yang tidak dipelajari di pesantren tapi keseluruhan kitab kuning yang ada mempunyai karakteristik/corak yang berbeda-beda.

Setiap cabang ilmu merupakan sistem tertutup dan di satu ilmu boleh jadi terdapat dalil-dalil dan pandangan bertentangan dengan yang di cabang ilmu lain. Para filosof dan mutakallim, sufi dan ahli metafisika, fakih dan ahli hadis masingmasing punya wacana sendiri, kadang-kadang bertentangan satu dengan yang lain.

Penulisan kitab kuning oleh ulama zaman dahulu merupakan tradisi keilmuan Islam karena, hampir pada tiap-tiap masalah terdapat lebih dari satu pendapat atau pendekatan berbeda dalam tradisi keilmuan Islam. Kalaupun ada perkembangan dalam tradisi keilmuan-yang terkadang terjadi akibat perkembangan politik itupun biasanya dalam bentuk pergeseran antar disiplin, di mana satu disiplin lebih mendapat perhatian daripada sebelumnya, sedangakn disiplin lain mundur. Banyak gerakan reformis, misalnya, telah menekankan fikih dari pada tasawuf dan tauhid, sementara gerakan reformis belakangan malah lebih menekankan kepada hadis dari pada mazhab fikih yang sudah mapan.

Kita sering merasakan unsur populis atau suasana anti elite di kalangan pendukung hadis. Elit ulama sering mengklaim hak-hak istimewa karena mereka memiliki ilmu canggih yang langka. Pokok hadis relatif sederhana dan dapat dipahami tanpa pendidikan khusus, selain itu semua hadis didukung wewenang Nabi. Karena itu, suatu hadis bisa dianggap sebagai argumen lebih kuat dari seluruh ilmu intelektual. Secara keseluruhan, ilmu-ilmu intelektual (al-um alaqliyah) seperti logika, filsafat, metafisika, kalam, ketabiban (thibb) semenjak

${ }^{13}$ Ibid, hlm. 334-335 
zaman klasik sedikit demi sedikit harus memberi lapangan kepadailmu-ilmu agama dalam arti sempit (al-ulum al-naqliyah: studi hadis, tafsir tradisional dan sebagainya). Proses ini pemiskinan tradisi intelektual Islam.

Sebagai intelektual muslim penguasaan kitab kuning sangat diperlukan untuk tempat rujukan. Maka pesantren berperan aktif melatih dan mendidik siswa untuk mahir dalam penguasaan kitab kuning.

\section{Kitab-Kitab Nahwu Dan Sharf Yang di Ajarkan di Pesantren Tradisional}

Tidak berlebihan jika pesantren tradisional merupakan genue bagi berkembangnya pesantren di Indonesia. Hal ini dikarenakan pesantren tradisional merupakan manifestasi dunia pesantren yang berusaha untuk tetap berada dalam rel tujuan awal pendirianya, yakni sebagai lembaga syi'ar (dakwah) dan pendidikan agama Islam. Sebagai sebuah lembaga pendidikan Islam, pesantren tradisional di awal perkembangannya hanya mengajarkan agama dengan sumber mata pelajaran berupa kitab-kitab berbahasa Arab yang masuk dalam kategori mu'tabarah. Pelajaran yang biasanya dikaji meliputi: Al Qur'an dengan tajwid dan tafsirnya; hadits dengan musthalahnya, bahasa Arab dengan nahwu, sharf, balaghah, arud, dan mantiqnya; fiqih dengan hukum-hukum dan ushul fiqihnya; serta akhlaq dengan warna tasawufnya. Kitab-kitab yang dipakai, pada umumnya juga terbatas pada hasil karya ulama abad pertengahan (antra abad 12-15) yang kemudian lebih dikenal dengan istilah kitab kuning.

Selain ilmu agama, Bahasa Arab merupakan pelajaran pokok yang harus diikuti dan dikuasai oleh para santri. Sebab, tingkat penguasaan terhadap tata bahasa Arab seringkali dijadikan tolok ukur kualitas seorang santri untuk mendapatkan predikat Kiai. Maka, tidak heran jika kitab-kitab nahwu, (Jurumiyah, Mutamimah, Imrithi, serta Al fiyah), kitab-kitab sharaf (al Amstilah at Tashrifiyah, Qawa'id al I'lal, Kaelani), serta kitab-kitab ilmu bahasa lainnya menjadi santapan keseharian di pesantren tradisional. Selain sebagai standar kualitas determinasi tinggi dalam mempelajari ilmu bahasa (nahwu dan sharaf) di kalangan santri tradisional juga disebabkan oleh berkembangnya jargon "As Sharfu Umm al Ulum wa al nahwu abuuhu” (sharaf adalah ibunya ilmu dan nahwu adalah bapaknya). 
Dalam bukunya Martin Van Bruinessen ${ }^{14}$ memaparkan kitab-kitab yang di pelajari di pesantren-pesantern yang berada di Nusantara diantaranya, Jawa, Sumatra dan Kalimantan serta urutan pembelajaran kitab dari yang mudah sampai sulit.

Dalam sistem tradisional, santri biasanya mulai mempelajari pengetahuan dasar tentang sharaf, yang berarti bahwa dia harus berusaha menghafal tabel-tabel pertama dari perubahan kata kerja dan kata benda. Karya yang paling sederhana dalam katagori ini adalah Bina'(Al-Bina'wa Al-Asas, karangan seorang Mulla AlDanqari). Setelah menguasai teks ini, santri kemudia mempelajari Al-Izzi (AlTashrif Li Al-Ïzzi karangan Ïzzuddin Ibrahim Al-Zandali atau Al-Maqshud fi AlSharf, sebuah karya anonim yang sering dianggap sebagai karya Abu Hanifah). Setelah melampaui tingkat ini, santri akan beralih kekarya pertama tentang nahwu sebelum melanjutkan mempelajari karya sharaf yang lebih sulit (jika ia memang pernah sampai mencapai tingkat ini). Salah satu karya yang paling gampang dan paling populer mengenai ilmu nahwu adalah Áwamil (Al-Áwamil Al-Miá, karangan Äbd Al-Qahir ibn Ábd Al-Rahman Al-Jurjani, Wafat $471 \mathrm{H}$ ), yang berisi sebuah daftar situasi yang menentukan harakat huruf akhir dari kata benda dan huruf-huruf hidup yang mengikuti konsonan akhir dari kata kerja. Setelah itu, santri dapat beranjak kekitab Jurmiyah (Al-Muqaddimah Al-Ajurmiyah, karangan Setelah itu, santri dapat beranjak kekitab Jurmiyah (Al-Muqaddimah AlAjurmiyah, karangan Abu Äbdullah Muhammad b. Daud Al-Shahaji b. Ajjurum, wafat pada $723 \mathrm{H})$.

Kurikulum pendahuluan ini lazim berlaku di berbagai wilayah yang cukup luas. di pesantren Jawa abad ke-19 dan di surau Sumatra Barat. Karya-karya yang sama juga masih digunakan, tetapi dengan perubahan-perubahan tertentu, Bina'dan Ïzzi adalah karya yang paling terabaikan dalam daftar tersebut, karna lebih mengutamakan karya-karya yang lebih serius, tetapi kedua karya tersebut tampaknya telah mempertahankan tempatnya lebih baik di Jawa Barat dan Sumatra daripada Jawa Tengah dan Timur. Sebuah karya baru yang bersifat pengantar (namun juga bersifat tradisional) yang sangat populer di pesantren Jawa adalah Amtsilah Tashrifiyah (Al-Amsilah Al-Tasrifiyah li Al-Madaris Al-

\footnotetext{
${ }^{14}$ Martin van Bruinessen lahir di Schoonhoven, Utrecht, Belanda, 10 Juli 1946 adalah antropolog, orientalis, dan pengarang Belanda.
} 
Salafiyah, yang berisi tabel infleksi), karya pengarang Jawa Muhammad Ma'sum bin Áli dari Jombang. Teks-teks pengantar yang lain juga banyak ditemukan. Pada tingkat selanjutnya, kitab syarah yang ditulis oleh pengarang Mesir Muhammad Üllaisy (w. 1881), Hall Al-Ma'qud Min Nazhm Al-Maqshud, dipelajari, sebagai pengganti, atau bersamaan dengan, Al-Maqshud, ini biasanya diikuti dengan penjelasan yang panjang lebar tentang Ízzi, kailani (yang diberi nama mengikuti pengarangnya, Äli b Hisyam Al-Kailani, yang tentang dirinya tidak ada informasi terperinci yang saya ketahui), yang sekarang merupakan kitab sharaf yang banyak dipakai.

Urutan mengkaji kitab nahwu biasanya sebagai berikut: setelah Jurmiyah, Imriti (versi Jurumiyah dalam bentuk bait-bait sajak), dan kemudian lagi kitab syarah yang lebih mendetil, Mutammimah, atau langsung ke Alfiyah yang biasanya di pelajari bersama-sama sebuah syarahnya. Imriti (Al-Durrah AlBahiyah, karangan Syaraf b Yahya Al-Anshari Al-Imriti), Mutammimah (dari Syams Al-Din Muhammad b. Muhammad Al-Ruáini Al-Haththab), dan Alfiyah (dari Ibn Malik) dengan kitab syarahnya yang terkenal Ibnu Äqil (dinamakan demikian mengikuti nama pengarangnya, Äbdullah b. Äbd Al-Rahman Al-Äqil) yang sejak lama sudah umum dipakai, dan digambarkan oleh Van den Berg dan Drewes, bersama-sama dengan berbagai kitab syarah lainnya yang masih ada tetapi tampaknya kurang populer. Kitab yang mereka sebutkan, tetapi sering ditemukan, adalah Asymawi, sebuah syarah atas Jurumiyah yang ditulis oleh seorang yang bernama Ábdullah b. Äsymawi. Sementara kitab syarah atas kitab Alfiyah, yang dituliskan akhir abad ke-19, adalah karangan mufti madzhab Syafiíyah di Makkah, Ahmad b. Zaini Dahlan, yang biasanya disebut Dahlan Alfiyah. ${ }^{15}$

Qathran Nada'(Wa Ball Al-Sada'), karangan Ibnu Hasyim (w.761/1360), yang sangat populer pada abad ke-19, juga masih banyak dipakai, karya pengarang yang sama, Qawaíd Al-I'rab, dipakai terutama dalam bentuk bait sajak (oleh Yusuf bin Abdul Qadir Barnawi), juga, terdapat sebuah terjemahan bahasa Maduranya.

Dalam kadar tertentu, karya-karya klasik digantikan oleh bahan-bahan pelajaran yang lebih modern. Pada tahun 1921. Konsul Belanda di Jiddah, E,

${ }^{15}$ Martin van Bruinessen, hlm. 168-170 
Gobee, mengamati bahwa di sekolah-sekolah pemerintah di Hijaz, kitab Alfiyah tidak lagi menjadi bagian dari kurikulum pelajaran bahasa, tetapi sudah digantikan dengan karya modern, Qawaíd Al-Lughah Al-Árabiyyah, suatu serial buku teks karya pengarang Mesir, Hafni Bak Nashif dkk. (Gobée 1921). Pada tahun 1930an, buku-buku ini dipakai di madrasah-madrasah Sumatra Thawalib yang relatif modern di Sumatra Barat, bersama-sama dengan buku-buku teks karya pengarang Mesir pada waktu itu dan buku-buku yang ditulis oleh ulama setempat yang telah belajar di Mesir.

Buku teks tata bahasa yang banyak menonjol di sini adalah Nahwu Wadhih (An-Nahw Al-Wadhih Fi Qawaíd Al-Lughah Al-Árabiyah), yang ditulis dua penulis Arab, Áli Jarim dan Mushtafa Amin (yang banyak tersedia dalam edisi Lebanon dan Mesir yang dicetak ulang secara fotomekanis). Buku ini juga sudah dipergunakan di Sumatra Barat sejak tahun 1930-an, bersamaan dengan buku AlBalaghah Al-Wadhihah, karangan kedua penulis yang sama.

Dari paparan diatas dapat disimpulkan ada beberapa kitab nahwu yang diajarkan di pesantren-pesantren tradisional diantarantanya Áwamil, Jurmiyah, Imriti, Mutammimah, Alfiyah, Qathran Nada', Qawaíd Al-I'rab, Qawaíd AlLughah Al-Árabiyyah, dan Nahwu Wadhih.

Kitab Al-Awamil merupakan kitab tatabahasa Arab terkenal dari kitab-kitab kuning yang digunakan di pesantren-pesantren di seluruh kawasan Nusantara. Naskah Kitab Al-'Awamil berisi tatabahasa Arab yang mengandung kajian kaidah struktur kalimat bahasa Arab dengan konsekuensi perubahan i'rab (bunyi akhir kata) berdasarkan posisi kata pada suatu kalimat. Disiplin ilmu bahasa Arab tentang tatabahasa semacam ini dikenal dengan sebutan Ilmu Nahwu. I'rab merupakan fenomena bahasa yang hanya terdapat dalam struktur kalimat bahasa Arab.

Kata Awamil merupakan bentuk jama dari kata 'amil, yang berarti kata-kata yang memberi pengaruh/ penentu terhadap i'rab kata di depannya. Isi kitab ini menekankan berbagai penentu i'rab kata Arab dalam struktur kalimat.

Jurmiyyah adalah salah satu kitab yang banyak dipakai di pesantrenpesantren tradisional karena kitab ini merupakan kitab nahwu yang paling populer dan sangat masyhur di kalangan para santri yang belajar nahwu dan sharaf, karena 
mudahnya uslub dan metode penyampaiannya hal menyebabkan banyak orang lebih suka belajar bahasa arab pakai matan jurmiyah ini.

Nadhom Al-Imriti ini merupakan matan Kitab Jurumiyyah, kitab ilmu nahwu yang diubah menjadi bentuk nadhom / natsar / sya'ir. Pengarangnya AlMuallamah Syeikh Syarafuddien Yahyaa Al-Imrithi Rohimahulloh. Di kalangan santri, kitab ini menjadi salah satu sorogan favorit fan ilmu alat lanjutan. Umumnya diberikan setelah tahapan kitab jurumiyyah dapat terhafal dan terpahami dengan baik. Dengan cara penyampaian nadhom seperti ini, para pembelajar lebih terbantu ingatannya atas hafalan yang sangat muskil sekalipun. Isi nadhom Imriti antara lain terdiri dari bait-bait : Muqoddimah, Bab Kalam, Bab I'rob, Bab Alamat I'rob, Bab Alamat Nashob, Bab Alamat Khofad, Bab Alamat Jazm, dst. Lengkap mengenai prinsip-prinsip dasar Ilmu Nahwu

Kitab Mutammimah Buku ini berisi penjelasan tentang struktur dan tata bahasa arab yang baik dan benar. Buku ini bisa dijadikan perantara untuk mengkaji kitab Nahwu Ajurumiyyah dan Kitab Alfiyah. Buku ini berisi materi yang padat, disusun dengan bahasa yang lugas dan mudah dipahami. Buku ini juga dilengkapi dengan contoh-contoh yang diambil langsung dari ayat-ayat suci al-Qur'an, sehingga membuat buku ini pantas untuk dijadikan salah satu referensi buku bacaan ilmu bahasa arab.

Alfiyah, Kitab yang satu ini juga lumayan terkenal, kitab ini berbentuk manzumah (sya'ir), banyak santri yang telah berhasil menghafalnya, bahkan mereka sangat-sangat hafal, sehingga jika di minta menghafalnya dari belakangpun sebagian santri sepertinya ada yang mampu melakukannya.

Kitab alfiyah memiliki banyak syarah atau penjelasan, salah satu yang terkenal adalah syarah miliknya ibnu aqil, kitab ini lumayan bagus untuk pelajar nahwu lanjutan bahkan lumayan bagus juga buat pemula, karena disampaikan dengan uslub / metode yang mudah dipahami, sehingga banyak perguruan tinggi yang memakainya.

Qathran Nada'(Wa Ball Al-Sada'), Kitab nahwu yang satu ini juga lumayan populer dipakai sebagai muqarrar atau kurikulum pelajaran nahwu terutama di berbagai perguruan tinggi khususnya di negeri timur tengah, memang kurang cocok untuk pemula, namun bagi kalian yang sudah belajar nahwu sejak lama, 
bisa saja memperdalam pengetahuan nahwu sharaf kalian dengan membaca dan mempelajari kitab ini.

Qawaíd Al-I'rab merupakan adi karya luhur Syekh Yusuf bin Abdul Qodir al Barnawi yang memuat kaedah-kaedah dalam menerangkan l'rob, yang merupakan salah satu cabang dari ilmu Nahwu yang harus di pelajari oleh para santri supaya dapat memahami secara benar al Qur'an dan Hadits.

Kitab Maqosidu Qowaidul l'rob ini akan menghantarkan memahami kitab qowaidul i'rob secara mendetail dan menyeluruh karena disertai dengan penjelasan-penjelasan dari berbagai kitab syarah seperti Kifayatul Ashhab, Kawakib ad Durriyah, Tashil Nailil Amani, Mughni Labib, Nadhom Alfiyyah Ibnu Malik, Ibnu 'Aqil, Jami'ud Durus al 'Arobiyyah, al Asymuni Syarh al Fiyah Ibnu Malik, Mutamimah al Jurumiyyah, Mukhtashor Jiddan Al Ajurumi-yyah, Faroid an Nahw al Wasimah dan lain-lain.

Dengan melihat hal tersebut penguasaan pokok-pokok dan tujuan kaidahkaidah i'rob (Maqosidu Qowaidul l'rob ) mutlak diperlukan, karena menguasainya secara mendetail merupakan kunci dan syarat untuk dapat mengkaji ajaran islam secara luas dan mendalam bagaikan lautan.

Qawaíd Al-Lughah Al-Árabiyyah karya muhammad al-Hifni ibn Muhammad Khalil Nasif (w. 1337 H.) bersama dengan rekan-rekannya telah menyusun kitab ad-Durusun Nahwiyah dan ad-Durusul Balaghah pada dekade 1890an. Kedua buku ini kemudian diberikan referensi oleh Kementrian Pendidikan dan juga Syaikh al-Azhar pada waktu itu, untuk diajarkan kepada pelajar di sekolah menengah Mesir. Pada perkembangannya kedua buku tersebut dikompilasikan menjadi satu buah buku Qawaid al-Lughah al-Arabiyyah litalamidz al-Madaris ats-Tsanawiyyah.

Ada dua pembahasan gramatika dalam kitab ini; Ilmu Nahwu \& Sharaf dan Ilmu Balaghah. Buku ini awalnya ditulis untuk pelajar penutur bahasa Arab di Mesir, karena itu tidak akan ditemui pendalaman kosa-kata (mufradat) ataupun dialog (muhadatsah). Pemaparan gramatika bertumpu kepada definisi dan contoh yang kadang diambil dari al-Quran atau syair Arab. Buku ini membantu pembaca untuk menghafalkan kaidah gramatika dan belajar menerapkannya dalam teksteks berbahasa Arab. 
Nahwu Wadhih (An-Nahw Al-Wadhih Fi Qawaíd Al-Lughah Al-Árabiyah), (Contoh yang jelas) ini adalah kitab yang dikarang oleh Ali Al Jarimy dan Mushtafa Amin, sebuah kitab kaidah bahasa arab (nahwu) yang disusun untuk tingkatan orang awam (Orang yang baru belajar bahasa Arab). Kitab ini ada tiga jilid. An Nahwul Wadhih adalah sebuah kitab yang ringan bahasanya namun berat muatan materinya. Sebuah kitab yang akan memberikan kita perkenalan dan gambaran umum tentang tata bahasa arab. Kitab Nahwu Al Wadhih adalah kitab yang banyak dipakai di pesantren-pesantren untuk mengajarkan Bahasa Arab pada para santrinya.

Kelebihan kitab ini adalah langsung membahas per kaidah dengan contohcontoh yang gamblang, persis seperti judul yang diberikan untuk kitab itu sendiri yakni Nahwu Al Wadhih (contoh yang jelas).

Kaidah-kaidah yang ada juga dijelaskan langsung dalam Bahasa Arab, sehingga dengan demikian para pembelajar yang menggunakan kitab ini dapat langsung berinteraksi dengan penjelasan-penjelasan bahasa Arab. Keunggulan lain adalah kosakata yang dipilih, kalimat yang digunakan sebagai contoh-contoh dalam buku ini juga sangat beragam, sehingga dapat memperkaya perbedaharaan para santri.

Sedangkan kitab-kitab sahraf yang diajarkan di pesantren-pesantren tradisional diantaranya Bina'(Al-Bina'wa Al-Asas, karangan seorang Mulla AlDanqari). Dalam kitab ini terdapat 35 bab yang membahas tentang perubahanperubahan kata, yang terdiri dari ruba'i dan tsulasi.

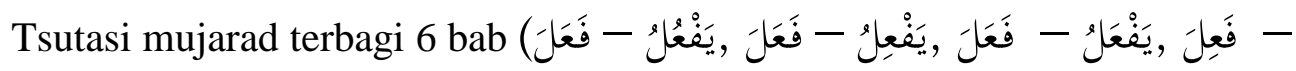

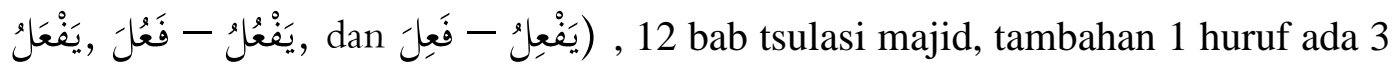

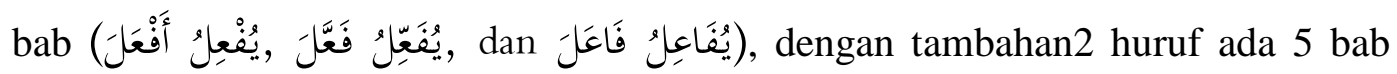

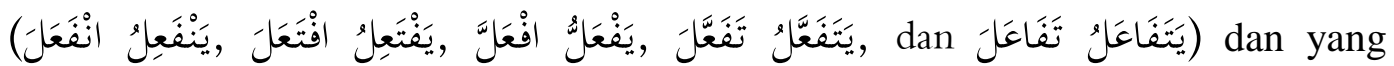
bertambah 3 huruf ada 4 bab (افْعَالَّ (يَفْعَالُ 
Sedangkan ruba'i mujarad ada 1 bab (يُفَعْلِلُ فَعْلَلرَ), mulhaq ruba'i ada 6 bab

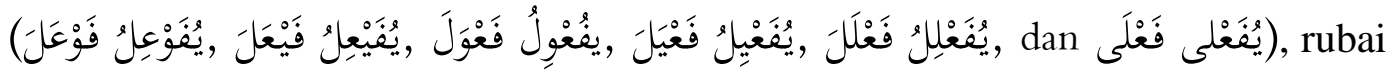
majid yang bertambah 1 huruf ada 1 bab (يَتَفَعْلَُ تَفَعْلَلَ) dan majid 2 huruf ada 2

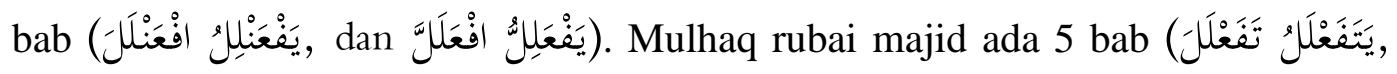

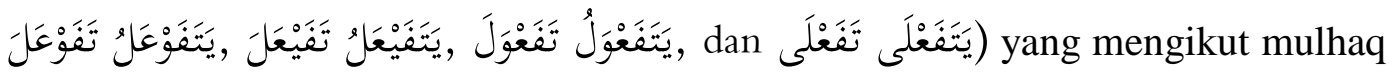

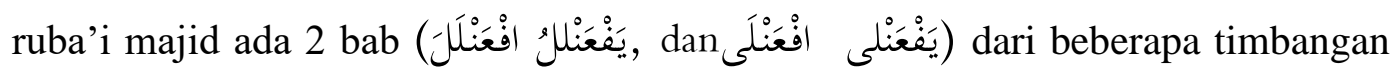
atau wazan ini santri bisa mengaplikasikannya dalam membaca kitab kuning.

Matan 'Izzi karangan Allamah Nahwi Izzuddin Al-Zanjani. Lebih dikenali sebagai Al-'Izzi. Matan ini matan kecil yang membincangkan asas ilmu Sorof. Digunakan di banyak pusat pengajian Islam serata dunia. Kitab ini mengulas perubahan bentuk kata (morfologi) dalam bahasa arab yang ditulis secara sistematis. Syeh Ali al- Kailani menulis penjelasan atas teks-teks dalam kitab tersebut. Beliau menjelaskan setiap teks dan mengembangkan uraiannya dengan memberikan contoh-contoh sesuai tema pembahasan. Kitab ini diawali dengan uraian perubahan bentuk fi'il dengan pola tsulasi mujarrod dan ruba'i mujarrod. Selanjutnya kategori fi'il mutaadi dan lazim, contoh-contoh tashrif, nun taukid tsakilah dan khofifah, kategori mudlo'af, mu'tal, dan yang berkaitan dengan penempatan hamzah. Pembahasan kitab ini dititup dengan ulasan isim zaman dan isim makan.

Al-Maqshud fi Al-Sharf, Kitab (Nadhom) Maqshud, merupakan adi karya yang luhur dan monumental dibidang ilmu sharaf, seperti yang disebutkan dalam kitab Rouhusy Syuruh. Kitab ini merupakan karya Syaikh Nu'man atau yang lebih popular dengan sebutan Imam Abu Hanifah, yang kemudian dinadhomkan oleh Syaikh Ahmad bin Abdurrohim, sedangkan kitab Al-Maqoshid Ash-Shorfiyah akan mengantarkan secera mendetail dan mendalam di dalam memahami kitab Nadhom Maqshud.

Amtsilah Tashrifiyah (Al-Amsilah Al-Tasrifiyah li Al-Madaris Al-Salafiyah, yang dikarang oleh Syeikh K.H Muhamamd Ma'sum Bin Ali ini menerangkan 
tentang ilmu sharaf yang dipelajari di Pondok-pondok Pesantren sama ada di Indonesia ataupun di Malaysia. Susunannya yang sistematis dan teratur, sehingga mudah difaham dan dihafal bagi para penuntut ilmu. kitab ini menjadi salah satu bidang studi yang tetap dikaji. Di Indonesia kitab ini masyhur dengan julukan “Tasrifan Jombang”. Keagungan kitab ini tak hanya terletak pada ilmu sharaf. Bila diteliti ternyata memuat makna filosofi tinggi.

Pada contoh fi'il tsulasi mujarrad misalnya, keenam kalimat tersebut yaitu :

$$
\begin{aligned}
& \text { فَعَلَ- يَفْعَلُ (فَتَحَ - يَفْتَعُ) , فَعَلَ- يَفْعِلُ (ضَرَبَ - يَضْرِبُ) ,فَعَلَ- يَفْعُعُ (نَصَرَ - يَنْصُرُ) } \\
& \text { فَعِلَ- يَفْعِلُ (حَسِبَ - يَحْسِبُ) ,فَعُعَ- يَفْعُلُ (حَسُنَ - يَخْسُنُ) ,فَعِلَ- يَفْعَلُ (عَلِمَ - يَعْلَمُ), }
\end{aligned}
$$

Dan terdapat juga dari sistematis susunan keenam kalimat diatas dirangkumi menjadi sebuah nazham yaitu :

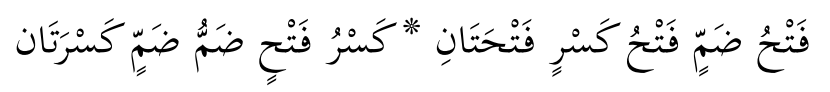

Bahkan, ia bukan sahaja mempunyai sistematika penulisan yang unik, malah memiliki filososfi yaitu :

Bahwa "pada awalnya sang santri/penuntut ilmu ditolong oleh orang tuanya (نَصَرَ) (nashara), sesampainya di pondok pesantren ia dipukul dan dididik (ضرَبَ) (dharaba). Kemudian setelah tersakiti dari dipukul, maka hatinya akan terbuka (فَتَحَ) (fataha). Seterusnya barulah ia akan menjadi orang yang mengetahui/pintar (عَلِمَ) ('alima) dan seterusnya menuntut ia agar berbuat baik (حَسُنَ) (hasuna). maka ia berharap masuk surga di sisi Allah swt (حَسبَ) (hasiba).

Kitab ini yang terdiri dari 60 halaman ini, telah diterbitkan oleh banyak penerbit, yang tidak sulit untuk dimiliki. Kitab yang kecil tetapi manfaat yang besar buat santri/penuntut ilmu dalam mengenal ilmu sharaf.

Hall Al-Ma'qud Min Nazhm Al-Maqshud, teks nazham "al-Maqshûd" sendiri terdiri dari 123 bait puisi dalam irama (bahr) "rajaz". Teks ini menghimpun ringkasan teori ilmu morfologi Arab (ilmu sharaf), karya Syaikh Ahmad ibn 'Abd al-Rahîm al-Thahthâwî (w. 1885), seorang juru tulis, sastrawan, sekaligus jurnalis asal Mesir. 
Ilmu sharaf merupakan salah satu cabangan utama dari ilmu linguistik Arab. Ilmu ini erat juga kaitannya dengan "ilmu nahwu" (sintaksis Arab). Ilmu sharaf mengkaji perubahan bentuk (derivasi/ tashrîf) satu kata ke bentuk yang lainnya, guna mendapatkan arti dan fungsi yang berbeda. Dalam rentang sejarah keilmuan bahasa Arab, terdapat banyak literatur ilmu morfologi Arab ini, mulai dari masa klasik hingga modern.

Nazham "al-Maqshûd" termasuk salah satu morfologi Arab di masa modern. Teks ini sangat populer, sehingga memiliki beberapa penjelasan dan komentar (syarh). Di antara syarh atas teks "al-Maqshûd" yang banyak dipedomani adalah "Hill al-Ma'qûd fî̀ Syarh al-Maqshûd", karangan linguis Arab asal Maroko yang sezaman dengan al-Thathâwî, yaitu Syaikh Muhammad ibn Ahmad 'Allîsy al-Maghribî (w. 1882).

Di pesantren-pesantren tradisional di Nusantara (NU), keberadaan teks nazham "al-Maqshûd" tentu tidaklah asing. Teks ini banyak tersebar, dipelajari, dan dihafal oleh para pelajar di pesantren-pesantren tersebut.

Dalam tradisi intelektual pesantren di Nusantara, morfologi Arab (ilmu sharaf) harus dikuasai oleh para pemula sebagai syarat mutlak untuk bisa membaca dan memahami teks-teks berbahasa Arab. Pembelajaran morfologi biasanya bersamaan dengan pembelajaran ilmu Sintaksis Arab (ilmu nahwu).

Di pesantren-pesantren tersebut, teks "al-Maqshûd" dipelajari sebagai lanjutan dari teks "al-Amtsilah al-Tashrîfiyyah" dalam bidang morfologi, yang bersama-sama dipelajari bersama teks "Mutammimah", yang merupakan lanjutan dari teks "al-Âjurûmiyyah" dalam bidang sintaksis.

\section{Metode-metode Pembelajaran Nahwu dan sharaf (Tata Bahasa)}

Seseorang dikatakan mampu membaca kitab kuning apabila ia mampu menerapkan ketentuan-ketentuan dalam ilmu nahwu dan sharaf. Ilmu nahwu adalah ilmu yang membahas tentang perubahan akhir kalimat, sedangkan ilmu Sharaf adalah ilmu yang membahas tentang perubahan-perubahan bentuk kalimat.

Menurut pandangan Kiai Zarkasyi, pendiri PP Gontor yang dikutip oleh H.M. Amin Haedari, metode pembelajaran di pesantren merupakan hal yang selalu mengalami perkembangan dan perubahan sesuai dengan penemuan metode 
yang lebih efektif dan efisien untuk mengajarkan masing-masing cabang ilmu pengetahuan. Untuk menghadapi perkembangan metode yang diterapkan dalam lembaga pendidikan pada umumnya, berbagai metode pendidikan pesantren yang bersifat tradisional dipandang perlu disempurnakan. Artinya, perlu diadakan penelitian yang seksama terhadap efektivitas, efisiensi, dan relevansi metodemetode tersebut untuk menemukan kelemahan dan keunggulannya. Segi kelemahannya diperbaiki sedangkan segi keunggulannya dipertahankan. Seruan yang sama disampaikan Abdurrahman Wahid yang diungkapkan kembali oleh Bruinessen. Kiai dan ustadz perlu melakukan pengembangan dan pembenahan ke dalam secara kontinyu, baik metodologi, teknologi dan aktivitas pendidikan agar mampu berkompetisi atau paling tidak mampu mengejar ketertinggalan dengan berpedoman memegang yang lama dan yang masih tetap layak serta mengambil yang baru tetapi lebih baik.

Dalam pembelajaran metode merupakan seperangkat cara sistematis yang ditempuh oleh guru dalam menyampaikan materi pembelajaran, agar pembelajaran dapat mencapai pada tujuannya. Metode juga dapat diartikan sebagai sebuah sistematika umum bagi pemilihan, penyusunan dan penyajian materi, dalam hal ini ini adalah materi bahasa Arab. ${ }^{16}$ Dalam pembelajaran metode memiliki peran sentral, bahkan masuk dalam sub sistem pembelajaran, bahkan dikatakan (At-Thariqah Ahammu minal Maddah) metode lebih penting dari materi. Hal ini menunjukan betapa pentingnya sebuah metode dalam proses pembelajaran hingga melebihi materi pembelajaranya sendiri.

Melihat kedudukan metode dalam pembelajaran, maka metode juga merupakan sesuatu yang bersifat praktis yang selalu ada dalam setiap pembelajaran, karena metodelah seorang guru dapat mentrasfer materi kepada siswa, metode juga merupakan wasilah atau saran untuk mencapai tujuan pembelajaran. Maka dari itu seorang guru dalam menerapkan metode harus mengacu pada tujuan-tujuan yang telah ditetapkan, demikian agar tujuan dapat tercapai dengan efektif dan efisien.

Ada beberapa metode yang bisa dipakai dalam proses pembelajaran nahwu dan sharaf (Qawaid) diantaranya:

${ }^{16}$ Ulin Nuha, Metodologi Super Efektif Pembelajaran Bahasa Arab (Yogyakarta:Diva Press, 2012).hlm. 158 


\section{Metode Deduktif الطريقة القياسية}

Pembelajaran dalam metode ini pada dasarnya menjelaskan terlebih dahulu kaedahnya, setelah siswa dapat memahami metode tersebut, mereka kemudian diminta untuk menghafalkan metode tersebut kemudian setelah melalui dua tahapan ini maka siswa diberikan contoh mengenai permasalahan yang telah dibahas. Setelah siswa menguasai dengan baik materi yang diberikan, guru memberikan lagi contoh lain yang lebih sulit dari contoh sebelumnya. Metode ini dalam metode Herbert juga disebut metode berfikir deduktif. ${ }^{17}$

Salah satu metode yang merupakan pengembangan dari metode qiyasiyah ini yaitu ditingkatan selanjutnya siswa disuruh membaca kitab-kitab klasik kemudian menjelaskan kedudukan dari setiap kata yang dibacanya. Sehingga dengan metode ini siswa diharapkan mampu menguasai dan memahami kitab-kitab klasik dengan baik.

2. Metode Induktif الطريقة الاستنباطية

Metode istinbathiyah disebut juga metode induktif. Metode istinbathiyah adalah metode yang dimulai dengan pemaparan contoh-contoh dengan memperbanyak latihan-latihan, kemudian dilanjutkan sampai kepada generalisasi atau pemaparan kaidah-kaidah yang umum. Metode ini sesuai digunakan kepada tingkat mutaqadimin (tinggi). Adapun pada tingkat mutawasit ataupun pemula, mereka belajar nahwu dengan nash sempurna, membaca dan memperbanyak latihan kemudian diikuti dengan pemahaman kaidah nahwu. ${ }^{18}$

Pada awalnya kemunculan metode ini dipengaruhi oleh Johan Frederich Herbart, pakar pendidikan asal Jerman. ${ }^{19}$ Yang sebelumnya metode deduktif telah berkembang di Eropa. Metode induktif adalah metode yang menggunakan pendekatan cara berfikir induktif yaitu cara berfikir dengan

${ }^{17}$ Muhammad Abdul kadir Ahmad, Thuruq at-Ta'lim al-Lughah al- 'Arabiyah, Cet 1 (Kairo: Dar asy-Syabab li-Thaba'ah, 1979), hlm. 191

${ }^{18}$ Ali Ahmad madhur, TadrisFonuun al Lughah al Arabiyah.(Riyadh: darul Shawaf.1991). hlm.338

${ }^{19}$ Muhbib Abdul Wahab, Epistemologi dan Metodologi Pembelajaran Bahasa Arab (Jakarta:UIN Jakarta Press, 2008).hlm. 179 
dimulai dari hal-hal yang bersifat partikular kemudian digieneralisasikan dan dijadikan sebagi kesimpulan atas beberapa kasus-kasus partikular lain yang memiliki kesamaan-kesamaan tertentu.

Abdul Qadir Ahmad (dalam: Zainul A’rifin) mengatakan ${ }^{20}$ :

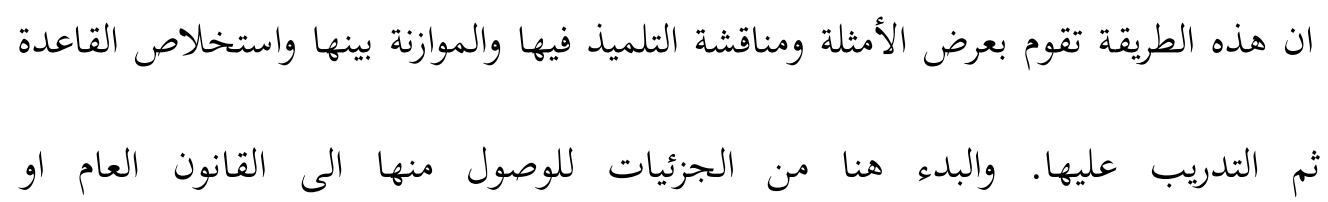

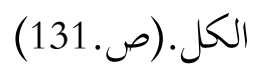

Artinya: Metode ini dilakukan dengan cara menyajikan contoh-contoh dan siswa mndiskusikan contoh-contoh tersebut, menganalogikan antara contohcontoh tersebut dan menarik suatu definisi kemudian mempraktekanya. Metode ini dimulai dari hal-hal partikular untuk mendapatkan kaidah umum dan menyeluruh.

Model pembelajaran dengan metode ini mengikuti lima langkah berikut: pendahuluan (muqaddimah), penyajian ( $\left.A^{\prime} r d\right)$, pengaitan (rabbt), penyimpulan kaidah (istinbath al-kai'idah) dan aplikasi (tatbiq). Peran pengajar dalam model pendidikan dengan metode ini adalah sebagai penyaji contoh-contoh partikular yang akan didiskusikan oleh siswa. Untuk itu pengajar dituntuk untuk mampu penyajikan contoh-contoh yang menarik dengan orientasi pada pencapaian tujuan dan tetap memperhatikan materi pembelajara sebelumnya, sehingga tercipta kesinambungan dan keterpaduan. $^{21}$

3. Metode kaidah dan terjemah الطريقة القواعد و الترجمة

Metode kaidah dan terjemah ini ditekankan pada penghafalan dan pemahaman kaidah nahwu dan juga penterjemahan. Metode ini bersifat umum karena bisa digunakan untuk mengajarkan bahasa yang lain bukan hanya bahasa Arab. Dalam metode ini, siswa diharapkan mampu memahami suatu teks atau wacana dengan menelaah isi dan kaidah yang terkandung

${ }^{20}$ Zainal Arifin. Al-Lughah Al-Arabiyah:Thara'iqu Wa asalibi Tadrisiha (Padang:Haiva press, 2010). hlm, 131

${ }^{21}$ Ibid 
dalam wacana tersebut. Untuk mengaplikasikan metode kaidah dan terjemah dalam pengajaran bahasa asing, dalam hal ini bahasa Arab, kita perlu melihat konsep dasar metode ini. Sebagaimana yang kita ketahui bahwasanya ada dua aspek penting dalam metode kaidah dan terjemah. pertama, kemampuan menguasai kaidah tata bahasa; dan kedua, kemampuan menerjemahkan. Dua kemampuan ini adalah modal dasar untuk mentrasfer ide atau pikiran ke dalam tulisan dalam bahasa asing (mengarang), dan modal dasar untuk memahami ide atau pikiran yang dikandung tulisan dalam bahasa asing yang dipelajari (membaca pemahaman).

Contoh penerapan metode ini dalam pengajaran nahwu adalah sebagai berikut :

a. Pendahuluan, memuat berbagai hal yang berkaitan dengan materi yang akan disajikan baik berupa appersepsi, atau tes tentang materi, atau yang lainnya.

b. Guru memberikan pengenalan dan definisi kaidah-kaidah tertentu dalam bahasa arab yang harus dihafalkan sesuai dengan materi yang akan disajikan, berikut terjemahannya dalam bahasa pelajar. Contoh : jika materi yang akan disajikan mengandung kaidah mubtada-khabar, maka langkah yang mungkin dilakukan adalah:

1) Mengenalkan konsep mubtada-khabar berikut definisi keduanya dan terjemahannya kedalam bahasa pelajar.

2) Memberikan contoh-contoh tentang materi mubtada-khabar

3) Setelah itu guru menjelaskan contoh-contoh tersebut seperlunya, misalnya ;

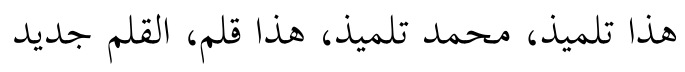

Dalam hal ini guru menjelaskan bahwa setiap dua kata yang digaris bawahi pada contoh-contoh itu merupakan pasangan mubtada-khabar yang tidak boleh tertukar, kemudian dianalisis sampai i'rabnya. Guru menjelaskan juga bahwa ada kategori mudzakar dan muannats yang masing-masing memiliki aturan tertentu.

4) Setelah itu, guru membimbing siswa untuk menghafalkan definisinya dengan baik dan benar. 
5) Setelah siswa mampu memahami kaidah nahwu (mubtada dan khabar), guru memberikan sebuah materi teks bahasa Arab, kemudian siswa mengidentifikasi isi teks bahasa Arab tersebut dengan menganalisis mubtada dan khabar dalam wacana tersebut.

6) Kegiatan akhir adalah guru melakukan evaluasi terhadap pemahaman siswa. $^{22}$

\section{Kesimpulan}

Dari pemaparan di atas, artikel ini dapat disimpulkan bahwa pesanter tradisional adalah tempat untuk belajar terkhusus untuk pembelajaran keagamaan, di pesantren tradisional bahan ajar yang di dipakai adalah kitab-kitab berbahasa Arab, oleh sebab itu untuk mengkaji semua kitab-kitab yang ada disana haruslah belajar ilmu alat terlebih dahulu khususnya nahwu dan sharaf atau biasa disebut qawaid.

Ada beberapa kitab nahwu dan sharaf yang bisa dipelajari oleh santri agar dapat memahami kitab-kitab lainnya, untuk kitab nahwu diantaranya, Áwamil, Jurmiyah, Imriti, Mutammimah, Alfiyah, Qathran Nada', Qawaíd Al-I'rab, Qawaíd Al-Lughah Al-Árabiyyah, dan Nahwu Wadhih. Sedangkan kitab sharaf, Al-Bina'wa Al-Asas, Matan 'Izzi, Al-Maqshud fi Al-Sharf, Amtsilah Tashrifiyah, dan Hall Al-Ma'qud Min Nazhm Al-Maqshud. Dalam pembelajaran qawaid kitab yang dipakai dimuali dari yang sederhana hingga yang sulit.

Kemudian ada beberapa metode yang bisa dipakai dalam pembelajaran qawaid diantaranya, metode qiasiyah atau diduktif, metode istimbathiyah atau induktif, dan metode qawaid wa tarjamah atau kaidah dan tarjamah.

\section{Daftar Pustaka}

Ahmad, Muhammad Abdul kadir. 1979. Thuruq at-Ta'lim al-Lughah al'Arabiyah, Cet 1. Kairo: Dar asy-Syabab li-Thaba'ah.

Amin Suma,dkk. 2002. Pondok Pesantren Al-Zaytun: Idealitas, Realitas dan Kontroversi, Jakarta: Lembaga Penelitian Universitas Islam Negeri (UIN) Syarif Hidayatullah.

Arifin, Zainal. 2010.Al-Lughah Al-Arabiyah:Thara'iqu Wa asalibi Tadrisiha. Padang:Haiva press.

\footnotetext{
${ }^{22}$ AcepHermawan.Metodelogipembelajaranbahasa Arab.(Bandung:Rosdakarya.2011).Hal. 173
} 
Azra, Azyumardi. 1999. Pendidikan Islam:Tradisi dan Modernisasi Menuju Milenium Baru. Jakarta:PT Logos Wacana Ilmu.

Barizi, Ahmad.. 2011. Pendidikan Intregratif:Akar Tradisi \& Intregasi Keilmuan Pendidikan Islam. (Malang:UIN Maliki Press.

Bruinessen, Martin Van. 1995. Kitab Kuning, Pesantren dan Tarekat, Bandung: Mizan.

Dahlan, Abdul Aziz, dkk. Suplemen Ensiklopedia Islam, Jakarta: PT. Iktiar Baru.

Dhofier, Zamakhsyari.1985. Tradisi Pesantren Studi Tentang Pandangan Hidup Jakarta : LP3ES.

Effendy, Ahmad fuad, 2005, Metodologi Pengajaran Bahasa Arab, Malang: Misykat

Faisal, Ismail. 1997. Paradigma Kebudayaan Islam: Studi Kritis dan Refleksi Historis, Cet. ke-2 Yogyakarta: Titian Ilahi Press.

Geertz, 1981. Abangan, Santri, dan Priyayi dalam Masyarakat Jawa, Jakarta: Pustaka.

Hermawan, Acep. 2011. Metodelogi pembelajaran bahasa Arab.Bandung:Rosdakarya.

Ismail, Faisal. 1997. Paradigma Kebudayaan Islam: Studi Kritis dan Refleksi Historis, Cet. ke-2. Yogyakarta: Titian Ilahi Press.

Madhur, Ali Ahmad. 1991. Tadris Fonuun al Lughah al Arabiyah. Riyadh: darul Shawaf.

Madjid, Nurcholish. 1997. Kaki Langit Peradaban Islam. Jakarta: Paramadina.

Nuha, Ulin. 2012. Metodologi Super Efektif Pembelajaran Bahasa Arab. Yogyakarta:Diva Press.

Suma, Amin, dkk. 2002. Pondok Pesantren Al-Zaytun: Idealitas, Realitas dan Kontroversi, Jakarta: Lembaga Penelitian Universitas Islam Negeri (UIN) Syarif Hidayatullah.

Sutrisno, Sejarah Walisongo Misi Pengislaman di Tanah Jawa, Yogyakarta: GRAHA Pustaka.

Turmudi, Endang. 2004. Perseligkuhan Kyai dan Kekuasaan. Yogyakarta:Lkis.

Wahab,Muhbib Abdul. 2008. Epistemologi dan Metodologi Pembelajaran Bahasa Arab. Jakarta:UIN Jakarta Press. 